\title{
Media History and the Mediatization of Everyday Life
}

\author{
Kortti, Jukka Petteri
}

2017-03-06

Kortti , J P 2017 , ' Media History and the Mediatization of Everyday Life ', Media History, vol. 23 , no. 1 , pp. 115-129 . https://doi.org/10.1080/13688804.2016.1207509

http://hdl.handle.net/10138/231338

https://doi.org/10.1080/13688804.2016.1207509

cc_by_nc

acceptedVersion

Downloaded from Helda, University of Helsinki institutional repository.

This is an electronic reprint of the original article.

This reprint may differ from the original in pagination and typographic detail.

Please cite the original version. 


\title{
Media History and the Mediatization of Everyday Life
}

\section{Jukka Kortti}

\section{Article (Accepted version)}

Post-print (ie final draft post-refereeing)

Original citation: Kortti, Jukka (2016), Media History and the Mediatization of Everyday Life. Media History ISSN 1368-8804 (Print), 1469-9729 (Online)

\begin{abstract}
M ediatization became a central concept in media studies in the 2000s, and it has also attracted critical discussion among media scholars. One part of the criticism of the concept concerns its relevance in relation to the history of media. In this article, I discuss the concept of mediatization in media history studies, especially when it comes to everyday life. I am predominantly interested in its 'weak form' - particularly the idea that mediatization is a historical process that depends strongly on the historical context. The article suggests that mediatization should be located in specific historical situations and in the meanings of history. Firstly, the concept should be seen as a process that is realized inside the meta-processes of globalization, individualization and commercialization - not as its own meta-process. Secondly, when adapting the concept to the socio-cultural factors of media history, it should be placed in the creation of world views. The article suggests that mediatization as a concept is most useful in media history studies when it is applied in studying the role of media in the history of everyday life.
\end{abstract}

Keywords: media history, mediatization, social history, media and worldview, mentalities, media and traditions 


\section{Introduction}

In recent decades, the significant increase of media historical studies has created the demand for a definition, if not a theory, of what media history is. This need stems not only from the newness of the field as such, but also from the ambiguities about its object in the first place and the omnipresence of media on the other: media has played a role in almost all areas of culture and society long before our digital age. Therefore, studying the history of communication can be approached from various disciplines such as history, sociology, economics, political science, arts, anthropology, and - media studies.

On the other hand, this problem, if it is a problem, concerns the latter as well. In media studies, there has been a problem historically regarding the disciplinary identity of communication and media studies when it tries to define itself as distinct from other disciplines. One way to resolve the problem is to launch a new concept, such as mediatization. ${ }^{1}$ In other words, media history is hardly a coherent field and media studies will probably never arrive at a truly stable point. ${ }^{2}$ Still, could mediatization also be a relevant concept for studying the history of communication?

In this article, I discuss the concept of mediatization in media history studies. I am predominantly interested in its 'weak form' - the idea that mediatization is a process that depends strongly on the historical context including culture, politics and economy ${ }^{3}$, and that it is a long term process ${ }^{4}$. I am particularly interested in sociocultural factors and mediatization in terms of everyday life.

The purpose of this article is to provide guidelines on how to insert the concept of mediatization into media history studies, particularly on how to locate the concept in studying the history of media. Firstly, I discuss the criticism and problems of the concept of mediatization in media history, and secondly, I locate the concept of mediatization in media history studies in regards to social history, particularly with regard to the concept of mentalities. Besides using common features of media history and certain particular studies, I also refer to my own empirically based studies on the history of television.

\section{Historical factors that shape media}

As a media historian, I have taken for granted, in a sense, that the media has had an important role in history and that it has conveyed changes in society, at least since the early modern period and Gutenberg. I think that the basic idea of media sociology, that media affects society and culture, is relevant. For instance, in my studies on the history of television and on the media and history culture, I have referred to the writings of media sociologist John B. Thompson' $\mathrm{s}^{5}$ ideas about 'mediazation', which have been seen as attempts at an early conceptualization of mediatization. ${ }^{6}$ However, the central theme in my approach to media history is more an attempt to show how major structural factors - technological, political and economic, and social and cultural transform media in historical modernisation processes. As a historian I want to emphasise the context of the emerging and developing of media technologies. This is presented in Figure 1. 
Figure 1: The changing structural factors influencing media development

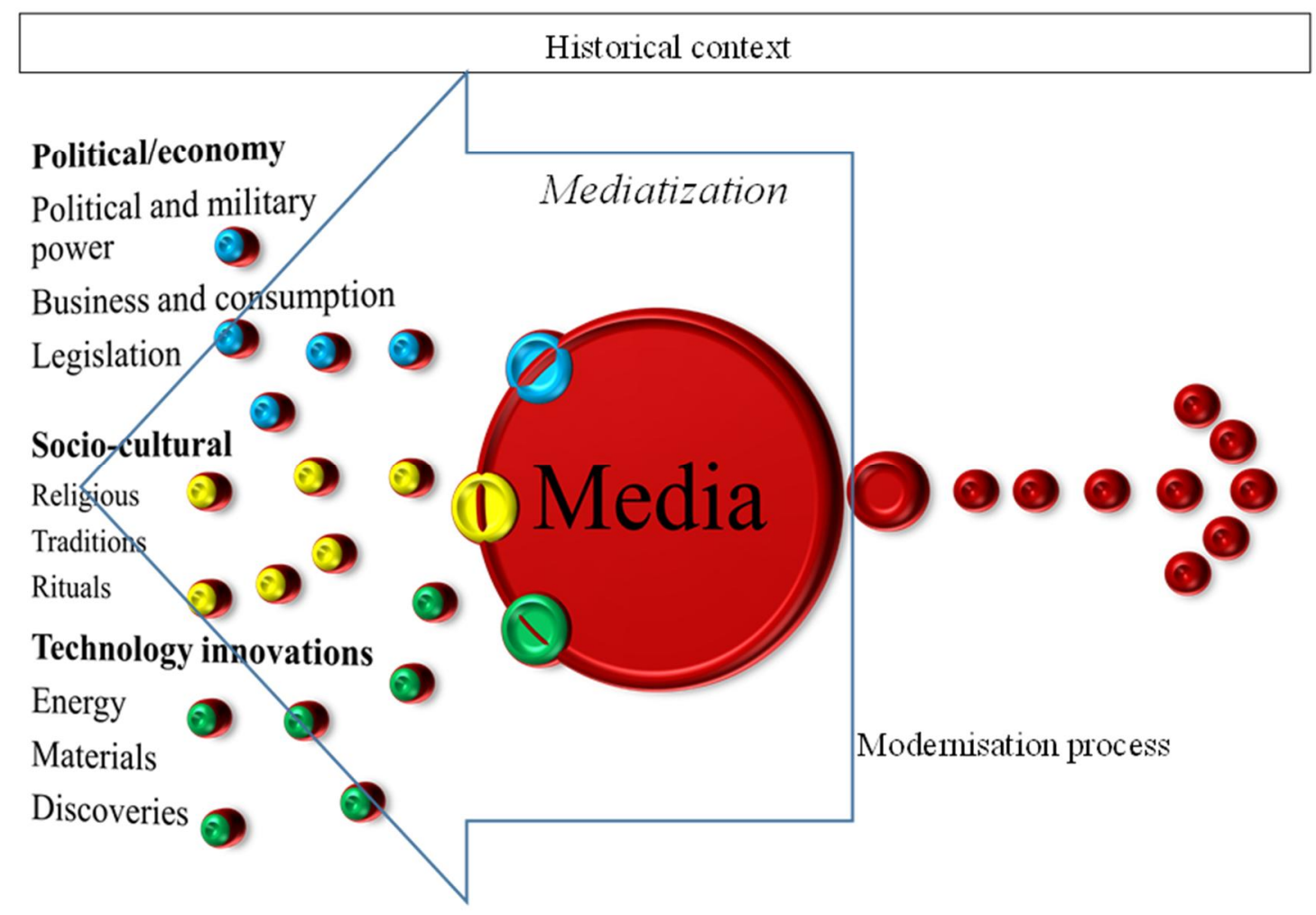

Firstly, without being technologically deterministic, it is clear that technology innovations such as the printing press, telegraph and microchip, the applications of electricity as well as the exploitation and use of minerals and plastic have shaped and created media.

Secondly, politics and the economy have often been central to the development of media. Gutenberg was highly dependent on capital and merchants trade men. The press was originally created to serve commerce when mercantilist governments needed information about current trade relations and other world affairs. When the press was politicized, censorship and other power related actions started to restrict media. Political choices have often been fundamental in the development of electronic media: what kind of a role does government have in the institutionalizing of a medium and how have new media such as broadcasting been financed (advertising of license fee). M edia systems are highly dependent on ideologies and multi-party political systems. Military industry is a different ball game from which several innovations in the media have emerged, namely, computers and the Internet but also older forms of communication such as the optical telegraph.

Thirdly, It is also crucial to understand that media does not develop if it does not meet human needs and cannot adapt to cultural and societal conventions. For instance, the printing of Bibles and other Christian texts 
were crucial for the diffusion of Gutenberg's innovation. The medium had to serve a need that already had a demand. Although capitalistic consumer production, commodification, and advertising is embedded with the idea of creating new needs, a new media application often needs to penetrate complicated and unforeseeable social and cultural meanings. We will come back to this notion later.

Nonetheless, it is clear that the approach above to media history does not exclude the idea that media also influences such structural factors: It is a two way process. If we look at the relationship between science and technology, for instance, it is obvious that the development of science has often been media technology dependent. The invention of the printing press was crucial for the 'scientific revolution' between the sixteenth and eighteenth centuries. Finding scientific anomalies, which are crucial for new paradigms to progress, was now much easier than before. The printing press provided a temporal and spatial frame of reference for scholars. ${ }^{7}$ In the same way, electronic media have since the telegraph enabled fast worldwide comparing of research results (meteorology, for instance). The opportunities provided by computers have been crucial for the development of science since the twentieth century.

\section{Mediatization and the development of media}

M ediatization became a central concept in media studies in the 2000s. Recently, it has also been a topic of heated discussion among media scholars. ${ }^{8}$ One part of the criticism of mediatization concerns its relevance in relation to the history of media. For instance, media scholars David Deacon $\&$ James Stanyer require a more systematic comparative study over time and space with regard to mediatization. ${ }^{9}$

Mediatization is supposed to help one to analyse the role of communication as an active agent of social change in different social and cultural spheres. ${ }^{10}$ Although the printing press and telegraphy were, first of all, helpful technologies for the scientist, they also had a significant effect on scientific thinking and its associated mentality in creating new worldviews. I have conceptualized the role of media in creating worldviews. ${ }^{11}$ My idea is that media operates both consciously (philosophy of life) and subconsciously (mentality) in creating a world view. I see that mediatization is located at the very heart of this process. This idea is represented in Figure 2. Besides science, it is the location where mediatization takes place also in political/economy and sociocultural factors (see Figure 1). And this process of creating world view could occur already before mass media and our postmodern world. 
Figure 2: Media and World View

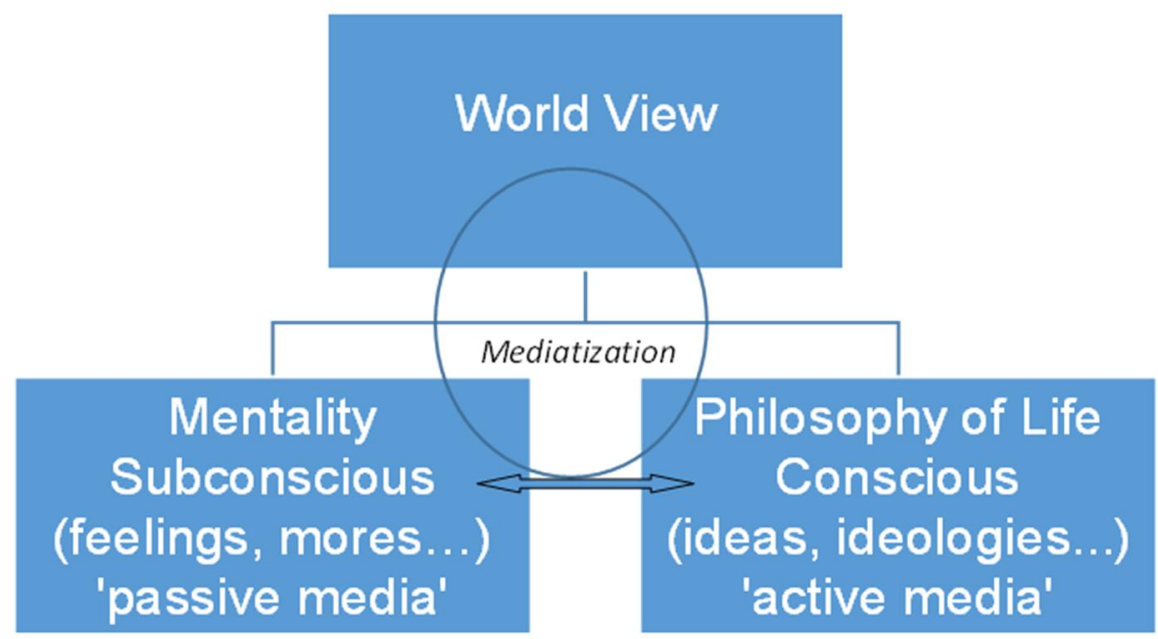

But before looking at this process with the help of some examples, let us look at potential problems regarding the concept of mediatization in history. Deacon \& Stanyer think that the concept is unsatisfactory as there is no consensus about the development of the mediatization process, no systematic research on historical change, and because studies involve mostly synchronic, not diachronic approaches. ${ }^{12}$

As mediatization theorists have emphasised in various articles, the concept implies historical change: mediazation is a long-term process influencing democracy and society, culture, politics and other conditions of life. ${ }^{13}$ But there are certain emphases in terms of how to see this process?

First of all, as a media historian, I incline towards the 'weak form' of mediatization simply because I see mediatization as a concept that conveys historical change. Secondly, I see that the idea of media logic - that media increasingly determines the actions of different social institutions and groups - is too deterministic when applied to recent media developments, not to mention media history.

Of the 'weak theoreticians', German media sociologist Friedrich Krotz has introduced the idea that mediatization should be discussed in relation to other 'meta-processes' of culture and society such as globalization, individualization and commercialization. ${ }^{14}$ However, I see that since these 'meta-processes' are all bound together and indeed interact with each other, it is more reasonable to see mediatization as a process that works within those metaprocesses - in the same way as mediatization works inside the creation of a worldview. Hence, rather than seeing mediatization as one of the metaprosesses, I see mediatization as a process that is realized inside the logics of globalization, individualization and commercialization as well as enlightenment, liberalism, capitalism and industrialization - not as a process in its own right.

I mostly agree with Hepp's notions of the 'moulding forces of the media' meaning how media specific the influence of mediatization is, how different media technologies have different qualities in the mediatization process. ${ }^{15}$ This reminds one of Joshua M eyrowitz's reference to the historian Theodore Roszak, who attacked M cLuhan's interest in media rather than messages. Roszak quoted the actress Jean Harlow, who said, when asked what she wanted for her birthday: 'Don't buy me a book; I gotta book.' On the other hand, as M eyrowitz notes, Harlow's plea is not that illogical if we change book to television in her reply. ${ }^{16}$ 
I agree with Deacon \& Stanyer that there should be more diachronic studies on mediatization. They emphasize that in order to analyse mediatisation as a continuous and linear process the potential for abeyance, accretion and acceleration in media development should also be taken into consideration. ${ }^{17}$ These are indeed central questions to the evolutionist and media archaeological approaches to media history.

While this article is not the place to discuss these approaches, it is important to notice that the strong form of mediatization usually sees the development of media as one of evolution. Although an evolutionary approach to media history is often a justified method, using 'media logic' is problematic - also in the media development of recent decades. As Deacon \& Stanyer note, there are lots of 'dead media' applications in social media. ${ }^{18}$ And as we know by looking back into media history, a specific form of media is sometimes discarded - even despite being a superior application (the Betamax vs. VHS videotape format war, for instance). On the other hand, as media scholar Stig Hjarvard notes, '[e]xtension, substitution, amalgamation and accommodation are important processes in mediatization' ${ }^{19}$, and, we might add, demands more empirical analysis at the same time.

I think, though, that the main problem in media studies nowadays is that there is too much talk about a revolution. The current digital culture is full of claims about the revolution of this-and-that - still is, despite the increase of media history studies in recent years.

However, we must remember that a synchronous approach can also be historical and reveal the development of media - and particularly its irregularities. According to the ideas of comparative history, a synchronous approach means studying the same time frame but across more than one geographical space. It could be done in several ways such as using within-case methods, for instance, which aim to find agreements, differences and variables. It is interested in the presence or absence of ideas, abstractions of reality. This kind of approach presumes a thorough knowledge of the social or cultural phenomenon under question in order to know the common characteristics and patterns of the phenomenon, as the ideal types must capture and accentuate these common features. ${ }^{20}$

This kind of approach could be useful in mediatization research when studying a certain era that is somehow hypothesised as being crucial in media history, such as the domestication of broadcasting. As Hepp et. al. emphasise in their response to Deacon $\&$ Stanyer ${ }^{21}$, mediatization research is not only interested in locating the objects of research within a historical frame, but also to history specific, contextual realizations which could reveal 'mediatization waves'.22 But this surely is not an easy task. For instance, in my studies on the sociocultural history of Finnish television, it was difficult to compare the research results arrived at in other countries since my data of television reminiscences was so unique internationally. ${ }^{23}$

Hepp et. al. also oppose the demand for more 'diachronous' empirical mediatization research saying that it is problematic, especially when it comes to everyday practices. They also argue that diachronic studies are not even fundamental for mediatization research. ${ }^{24}$ Indeed, it is often problematic, even impossible to find relevant, solid data to compare through time since data sources are so limited. A significant limitation of comparative history in general, and in synchronous studies too, is that it is usually based on secondary sources, often being the interpretation of interpretation. ${ }^{25}$

In history studies, however, these kinds of challenges are common since historians are used to making interpretations based on very variable sources - albeit to comply with source critic and other methodological grounds. Especially in making syntheses, approaches are mostly based on countless empirical studies as well as other interpretations. But this does not mean, however, that the ideas of mediatization could not be applied to these kinds of contributions. 
Hepp has also written that "mediatization" does not term a closed theory of media change but much more openly a certain panorama of investigating the interrelation between media communicative change and sociocultural change. ${ }^{26}$ Hepp has borrowed this idea of panorama from Bruno Latour. Hepp's idea in applying the concept of panorama to mediatization is that he sees mediatization as immersed in all human experience, not only in the macro level. This thinking also includes the idea that mediatization is a meta-process like other meta-processes.

British media scholars Peter Lunt and Sonia Livingstone, who have also contributed to the debate recently, suggest that before the idea of mediatization becomes a real paradigm in media studies, it should be conceived as a sensitizing concept. Under the idea, they see that media scholars should heighten historical awareness: "pushing us to go beyond a simplistic polarization of "now" and "before", or "old" and "new" media, or twentyfirst century and "the past" (a challenge of particular importance as analysis of "the digital age" threatens to eclipse or obscure nuanced analysis of earlier periods)'. They also suggest asking how mediatization intersects with or depend upon or add to the analysis of the metaprosesses mentioned. ${ }^{27}$ Hence their idea comes rather close to my view that mediatization works within the metaprocesses.

The idea of the panorama or to understand mediatization as a sensitizing concept in mediatization theorizing does not, however, help to define what the concept actually means. In a way, the problem concerns the overall definition of media. There is a danger that we end up telling 'a story where anything and everything is communication', as John Nerone ${ }^{28}$ cautions. One way to solve this problem is to redefine media as anything that communicates meaning, such as the environment, as media philosopher John Durham Peters ${ }^{29}$ has done recently. However, this kind of epistemological approach does not help us apply mediatization to media history studies. Hence, the question is raised as to whether the idea of mediatization, especially when applied to such a vaguely defined field as media history, is relevant after all.

When we apply the concept sufficiently and appropriately to the history of media, I think that as an idea, mediatization is relevant. Next, I select a few examples from media history, especially with reference to the social and cultural factors presented in Figure 1, to present how mediatization is a relevant tool in researching the history of media.

\section{Social history and mediatization}

If we look at Figure 1 above from the point of view of mediatization, the concept operates in economic and political factors and, most apparently, in socio-cultural factors. This does not mean, however, that mediatization in history would not have been realized also in terms of technology and innovation factors, as discussed above. Similarly mediatization unquestionably has had an important role in economics and politics through a variety of forms (PR, advertising, censorship, propaganda, etc.). However, let us next look at mediatization as 'the process whereby communication refers to media and uses media so that media in the long run increasingly become relevant for the social construction of everyday life, society, and culture as a whole', as Krotz has put it. ${ }^{30}$

Our questions are: Can we really talk about mediatization of everyday life before mass literacy and mass media? When did it actually start? And, first of all, has it been a linear process?

Before the modern era, the most important form of everyday media was visual religious communication, which has had a central role as a form of media for thousands of years. Since mass literacy is a novel phenomenon in history, religious images had an effect on people's worldview, especially in medieval Christian cathedrals, when art had a strong didactic importance. And since this religious worldview controlled every aspect of human life 
at that time, it also had an important role as an everyday media. If we widen the concept of media from actual media technologies to paintings, images, architecture and other religious art, mediatization has been an elemental part of civilization almost since its beginning. And this also concerns 'oral media' since sermons were central sources of information for communities right up until the twentieth century.

But if we outline the media to mean primarily modern media technologies, undoubtedly the crucial phase of mediatiatization in history is the coming of a typographic culture in the sixteenth century. One of the major consequences of the innovation of the printing press was a significant decrease in the monopoly of the church over information. From the point of view of social history, it is crucial to understand that when the printing press and literacy spread, the old hierarchical superstructures could not monopolize the Word anymore as they have done for almost five thousand years.

One of the most brilliant studies of this transition is Cheese and worms (II formaggio e i vermi) ${ }^{31}$ by the Italian historian Carlo Ginzburg. This classic of microhistory tells the story of an Italian miller called M enocchio, who spontaneously read books, religious texts and other material, and then, based on his reading, preached his own philosophy of life, and his own cosmology to other common people in the Italian countryside in the sixteenth century. Owing to his teachings he was accused of heresy during the Inquisition. The judges and priests could not understand that a common man, albeit literate, could develop his own philosophy of life and he was burned at the stake. The study shows how the mentality of a sixteenth-century miller differed from the 'official' mentality of that era.

The history of mentalities is interested in the emotional and irrational, and unconscious collective elements 'communities of belief'. ${ }^{32} \mathrm{M}$ entality has been seen as a collective, often automatic subconscious behaviour of everyday 'normal life' among the (ordinary) people. Menoccio was highly influenced, as was everybody at that time, by the religious images and texts he acquired from the Catholic authorities. But in addition, he also actively and independently read more about the world and made his own cosmology.

The concept of a philosophy of life as the reflected dimension of a world view depicts this active side (see Figure 2). It requires exceptional mental activity from an individual; it involves an attempt to systematise views about reality. In modern media, this reflected dimension is materialised in establishing a cultural magazine or fanzine or a weblog, for instance. But it could also mean active and independent use of media texts in forming one's own worldview. Hence, when M enoccio used printed books in developing his world view, mediatization took place when this active side met the subconscious, 'passive' forms of media. And, as Ginzburg notes: 'A case such as M enocchio's was made possible by two great historical events: the invention of printing and the Reformation'.33 So besides the medium, we need to take into consideration the major cultural movement of the time. In other words, mediatization in media history must be grasped as happening in a specific place and time.

However, we must remember that most of the first printed books were too expensive or targeted at professional communities such as clerks or doctors for centuries after the inventing of the printing press. The first cheap prints were so-called chap books, which were small books or pamphlets containing stories, poems, or religious tracts, telling stories about saints and romance. Besides ordinary people, noble women also read these stories. These small, cheaply produced booklets printed on a single sheet appeared in the sixteenth century, but the height of their popularity was in the following centuries. Chap books as well as broadside ballads, almanacs, pamphlets, religious tracts, and poetry were especially popular in the eighteenth century. 
So you could say that these books started the mediatization of everyday life in the modern era, even though this cheap literature concerned only a small minority of the population, namely, those who could read.

However, what was crucial from the point of view of individualization was when 'silent reading' (instead reading loud) became more common, which allowed individuals not only to form their own philosophy of life but also to acquire empirical knowledge from sources other than those of the authorities, as Menoccio did. This 'reading revolution' started not only critical and creative reading, but also private reading. ${ }^{34}$

Here, again, it is crucial to take into consideration the contextual processes surrounding and interacting with the development of media. At the same time as this popular print spread, the privatization of everyday life process started when bedrooms became more common among high- or middle-class citizens. Now you were able to read these small books silently on your own. In his view on the history of private life, historian Philippe Ariés sees the progress of literacy, caused by the printing press, and the development of new forms of religion together with changes in the role of the state as the major factors of privatization since the fifteenth century. ${ }^{35}$

According to Ariés, this privatization process reached its final point in the nineteenth century in terms of customs, habits, conventions, housing, family life etc. Owing to the rise of the capitalistic bourgeoisie, the home and family became a retreat and a place for leisure. Private and public life was separated and public life was controlled more by governments and private business. This however, concerned mostly the rising cities of the Western world. In the countryside, communality remained into the twentieth century. All in all, we must remember, as Ariés emphasizes, that changes in mentality are slow, much slower than political, social, even cultural change. Hence, mentality does not follow the periodization of history: instead traditions, mores and fundamental attitudes could last unchanged for long periods of time. ${ }^{36}$

\section{The mediatization of traditions?}

One way to approach the mediatization of everyday life in history is to analyse how traditions are adapted to changes in media culture. If we look at the early era of mass communication, most obviously this was realized in the early phases of the domestication of the media. For instance, people wore evening dress when they listened to classical concerts or wore their church clothes when they listened to religious services on the different telephone applications of broadcasting (e.g. Hungarian Telefon Hírmondó, Italian Araldo Telefonico and British Electrotelephone), also called the 'circular telephone'. ${ }^{37}$ The phenomenon of dressing up for shows transmitted to homes as in 'real concerts' could be found in the first years of radio and television as well. On the other hand, cinema (the collective 'Lumiére model' not the private 'Edison model') started according to the pattern provided by the theatre, vaudeville, panorama and magic lantern (phantasmagoria) shows and this movie going practice has basically remained until the twenty-first-century cinema culture: to experience film art and entertainment is a solid cultural convention that has a long history even before the invention of cinema.

However, although traditions may survive through time and changes in culture and society as in the practice of cinema viewing, they could also change radically along with modernisation. As a media technology, the circular telephone not only did not survive per se, but also the tradition to consume it 'courtly' soon vanished in actual broadcasting when it was domesticated. This is important to take into account when analysing mediatization processes in history: to see that there are breaks and continuities in media traditions. In order to present this argument in more detail, let us look at the role of traditions and rituals in the changing uses of Finnish television. 
Also in Finland, there was an awe-inspiring attitude towards television in Finland that was realized, among other things, in dressing up to watch the television in the first years of television broadcasting. There were also other distinctive features of early television culture. Before television became the property of nearly all social groups and significantly enhanced the privatization process of Finnish families, there was a short period characterized by a collective watching culture in the early years of television in Finland. The old tradition of neighbourly visits experienced a revival when people from the neighbourhood as well as from farther away gathered to view programmes together in households which had the apparatus. There could be numerous guests for many nights in a row. Often the spectators ranged from children to grandparents and from family members to fellow villagers. Talking and coffee drinking were an integral part of viewing television together. ${ }^{38}$

Serving coffee to visitors in particular was and still is at the very heart of the Finnish visiting culture. You could say that it is the most integral expression of Finnish hospitality. Coffee drinking became a ritual and central mode of social interaction in all Finnish social classes in the late nineteenth century and since then coffee breaks have set the pace of Finnish everyday life. ${ }^{39}$ After the short collective watching period, when television soon spread in Finnish households in the early 1960s, coffee drinking as a tradition continued and it was actually television that had to adapt to the tradition: first coffee then television. This kind of adaptation of television to a national cultural tradition can be found all over the world. For instance, it can be compared to the British tradition of watching television after tea - at least in the first decades of television. ${ }^{40}$ Another and more culturally specific tradition in Finland is watching television after sauna. Sauna is the most marked old Finnish tradition, and it is very much alive today in weekly family routines. A more universal example is the prime time's dependence on the time different cultures have dinner.

Hence while television had a radical impact on social interaction in the early days, many old Finnish traditions remained. Routine television habits were transformed and adopted into Finnish culture traditions. In this respect, television can be considered transmodern: ${ }^{41}$ television viewing incorporates habits that are both newer and older than television. The media can also be used to expand and cement traditions, instead of just challenging and undermining values and beliefs. ${ }^{42}$

But in the examples above, it was the media that had to adapt to the traditions rather than the traditions being mediatized. This does not mean, however, that Finnish traditions or practices did not have to adjust to television too. In the early days of television, this mostly concerned the rhythms of everyday life. For instance, the milking of cows in some Finnish farms was postponed due to the timing of certain television shows in the early days of television. Later in the early 1980s, when the Ten O'Clock News was launched on the Finnish commercial TV channel MTV, Finns delayed going to bed by some thirty minutes, according to time use research. ${ }^{43}$

\section{Conclusion and discussion}

To conclude, the basic idea is that mediatization operated within - not along with - the processes of globalization, individualization and commercialization in history before our digital era. Accordingly, media has affected globalized politics and economy since the nineteenth century at the latest. M edia has changed business and trade drastically at times, such as when printing was an example for industry in which production was organized by firms ${ }^{44}$ or when the telegraph became vital for the stock market within a very short period of time or how modern advertising took part in promoting mass consumer capitalist societies, for instance. But as we know, those changes can be approached in multiple ways. 
There are several approaches to media history and they are highly dependent on the respective research tradition. In the Anglo-American tradition, the approaches could be divided into the "media/technology school" and the "media/institution school". The former is associated with the medium theorists (Innis, M cLuhan, Postman, Carey) and their fascination with the philosophy and grand narratives of media and the latter is associated with the content and institutions of media and its relation to modernisation, democracy, and the public sphere. ${ }^{45}$ In Germany, on the other hand, there is a strong tradition of studying the history of journalism and newspapers and the definition of the concepts of "media" and "media history" are highly dependent on the research field in which they are studied: the approaches by the social and communication sciences (Kommunikationswissenschaft) are different from those of media culture studies (Medienwissenschaft) to media history. ${ }^{46}$

Since the 1990s, there has been a boom of media history in Finland - as in many Western countries. One could even say that the idea of generations in media historical studies, which emerged in the 1990s, especially by Paddy Scannel, ${ }^{47}$ has been a popular theoretical approach by Finnish media history studies. Particularly media historian Raimo Salokangas has adapted the concept for Finnish media history writing. The first generation study is usually an institutional history, an in-depth medium history: knowledge about how the institution works. This "basic research" creates the necessary basis and context for explaining the output of that institution, which is carried out by a second generation study. Salokangas calls this second level "communication history" when it comes close to general cultural history. ${ }^{48}$ The third generation is often an audience research concerned with the study of media history: how audiences have reacted to the broadcasting, cinema, press, etc. over time.

As a media historian who has written media histories that could be classified in all three of these generations, I could say that the idea of mediatization could be adapted to all of them. However, since the definition of the term is still rather vague, even confusing, it must be used only in specific cases that are sufficiently contextualised. In my doctoral study ${ }^{49}$ on the history of Finnish television advertising in the 1960s, my ambitious effort was to write a sort of a "total history" with reference to Fernand Braudel and the Annales School. Now, making sense of my work over a decade later, it looks rather more like a broad contextualisation of television advertising in the Finnish society and culture of the 1960 s than a histoire totale. John Nerone ${ }^{50}$ interprets the problem of this type of approach to be the function of the media which 'gets swallowed almost whole by all the things that the media mediate' which is actually the flip side of the views of media ecologists Innis and McLuhan, whose idea is that media consume everything else.

However, as I have tried to show through the examples, the most relevant way to adapt the idea of mediatization to media history is by grasping the role of media in everyday life, particularly as new media penetrate different kinds of traditions. They are often slow to change in order to be domesticated into everyday life. The diffusion of books was dependent not only on the spreading of literacy but also on the increased privacy available within individual households. Television, on the other hand, must have been adapted to different cultural conventions. The examples above about the history of Finnish television viewing tells us that when looking at such elemental features of mentality as traditions, the influence of the media is not linear and - first of all - does not follow any 'logic'. The idea of mediatization is, again, relevant when we concentrate on certain traditions in certain media, but also in certain historical contexts, including the temporal and spatial specifics of a culture.

Regarding the history of mentalities, however, it is worth mentioning that although the concept of mentality could provide fruitful approaches to media history studies, it has not proved to be entirely unproblematic. As 
the cultural historian Peter Burke, who has also studied the history of media, notes, historians may have successfully described the persistence of a mentality at a particular point but failed to explain how, when or why a mentality has changed. Another problem in the history of mentalities is in seeing 'traditional' and 'modern' as binary opposition 'belief systems'. ${ }^{51}$ Therefore, as I wanted to show through the examples above, applying the concept of mediatization to the study of the history of the media, the studies of the history of mentalities could also benefit from the approach.

When it comes to the different media history traditions mentioned above, it is obvious that the ideas of mediatization are most easily adapted to the third generation media history studies as well as to the cultural studies tradition. In other words, mediatization as a concept is most useful in media history studies when we are interested in the role of media in the history of everyday life.

\section{References}

Ampuja, M arko, Juha Koivisto, and Esa Väliverronen. "Strong and Weak Forms of M ediatization Theory. A Critical Review." Nordicom Review 35, Special Issue (2014): 111-123.

Aries, Philippe, "Introduction." In A History of Private Life III. Passions of the Renaissance, edited by Roger Chartier, 1-11. Cambridge \& London: The Belknap Press of Harvard University Press, 1989.

Balbi, Gabriele. "Radio before Radio: Araldo Telefonico and the Invention of Italian Broadcasting." Technology and Culture 51, no. 4 (2010): 768-808.

Braembussche, A.a. Van Den. "Historical Explanation and the Comparative M ethod: Towards a Theory of the History of Society. History and Theory 28, no. 1 (1989): 1-24.

Briggs, Asa and Peter Burke. A Social History of the M edia. From Gutenberg to the Internet. Cambridge: Polity, 2003.

Burke, Peter. History and Social Theory, second edition. New York: Cornell University Press, 2005.

Bösch, Frank. M ediengeschichte. Vom asiatischen Buchdruck zum Fernsehen. Historische Einführungen. Frankfurt ja New York, Campus-Verlag, 2011.

Deacon David and James Stanyer. "M ediatization: Key Concept or Conceptual Bandwagon? M edia, Culture \& Society 36, no. 7 (2014): 1032-1044.

Deacon David and James Stanyer. "'M ediatization and' or 'M ediatization of'? A response to Hepp et al." M edia, Culture \& Society 37, no. 4 (2015): 655-657.

Eisenstein, Elizabeth L. The Printing Revolution in Early M odern Europe. Cambridge: Canto, Cambridge University Press, 1993.

Ellis, John. Seeing things: Television in the Age of Uncertainty. London: I. B. Tauris, 2000.

Ginzburg, Carl. The Cheese and the Worms. The Cosmos of a Sixteenth Century M iller. Translated by John and Anne Tedeschi. London: Penguin Books, 1992/ 1976.

Hartley, John. Uses of Television. London and New York: Routledge, 1999.

Hepp, Andreas. "Differentation: Mediatization and Cultural Change." In M ediatization. Concept, Changes, Consequences, edited by Knut Lundby, 139-157. New York: Peter Lang, 2009. 
Hepp, Andreas. "M ediatization, M edia Technologies and the 'M oulding Forces' of the M edia." The International Communication Association's 2011 Virtual Conference, 23 M ay - 10 June 2011. http:// www.andreashepp.name/Blog/Eintrage/2011/5/26 Paper auf der ICA-Tagung und mehr files/Hepp.pdf : 1-23.

Hepp Andreas. Cultures of Mediatization. Cambridge: Polity Press, 2013.

Hepp Andreas, Stig Hjavard, and Knut Lundby. K. “M ediatization: Theorising the Interplay between M edia, Culture and Society." M edia, Culture \& Society 37, no. 2 (2015): 314-322.

Hjarvard, Stig. "From Bricks to Bytes: The Mediatization of a Global Toy Industry." In European Culture and the M edia, edited by Ib Bondebjerg and Peter Golding, 43-64. Bristol: Intellect Books, 2004.

Hjarvard, Stig. "The M ediatization of Society. A Theory of the Media as Agents of Social and Cultural Change." in Nordicom Review 29, no. 2 (2008): 105-134

Kettunen, Pauli. "Työväenkysymyksestä henkilöstöpolitiikkaan." In Suuryritys ja sen muodonmuutos. Partekin satavuotinen historia, edited by Antti Kuusterä, 266-380. Helsinki: Partek Oyj Abp, 2002.

Kortti, Jukka. M odernisaatiomurroksen kaupalliset merkit. 60-luvun suomalainen televisiomainonta (The Commercialised Signs of M odernisation. Finnish Television Advertising in the 1960s). Helsinki: SKS, 2003.

Kortti, Jukka. "M ultidimensional Social History of Television. Social Uses of Finnish Television from the 1950s to the 2000s." Television \& New M edia Volume 12 Issue 4 (July 2011): 299-313.

Kortti, Jukka. "Generations and M edia History." In Broadband Society and Generational Changes Series:

Participation in Broadband Society - Volume 5, edited by Leopoldina Fortunati and Fausto Colombo, 69-93.

Frankfurt am M ain, Berlin, Bern, Bruxelles, New York, Oxford, Wien: Peter Lang, 2011.

Kortti, Jukka. "Television Creating Finnish Consumer Mentality in the 1960s." In Finnish Consumption. Emerging Consumer Society between East and West, edited by Visa Heinonen \& Matti Peltonen, 154-176. Helsinki: SKS, 2013.

Kortti, Jukka and Tuuli Anna M ähönen 2008. "TV Remains In and According to Reminiscences: Media Ethnography, Oral History and Finnish Third Generation Media History." European Journal of Communication Vol.24, No.1, (March 2009):49-67.

Krotz, Friedrich. "Mediatization: A Concept with Which to Grasp M edia and Societal Change." In M ediatization. Concept, Changes, Consequences, edited by Knut Lundby, 21-40. New York: Peter Lang, 2009.

Lange, Matthew. Comparative-Historical M ethods. London: Sage, 2013.

Lundby, Knut. "Introduction: 'M ediatization' as Key." In M ediatization. Concept, Changes, Consequences, edited by Knut Lundby, 1-18. New York: Peter Lang, 2009.

Lunt, Peter and Sonia Livingstone. "Is 'mediatization' the new paradigm for our field? A commentary on Deacon and Stanyer (2014, 2015) and Hepp, Hjarvard and Lundby (2015)." Media, Culture \& Society 2016, Vol. 38(3) 462-470.

M eyrowitz, Joshua. No Sense of Place. The Impact of Electronic M edia on Social Behavior. New York \& Oxford: Oxford University Press, 1985. 
Nerone, John. "Approaches to M edia History." In A Companion to M edia Studies, edited by Angharad N. Valdivia, 93-114. Oxford: Blackwell Publishing, 2003.

Nerone, John. "M apping the Field of M edia History." In The International Encyclopaedia of Media Studies. Volume 1. Media History and the Foundations of M edia Studies. Edited by Angharad N. Valdivia (general editor) and John Nerone (volume editor). Oxford: Wiley-Blackwell, 2013.

O'Sullivan, Tim. Television M emories and Cultures of Viewing, 1950-65. In Popular Television in Britain: Studies in Cultural History, edited by John Corner, 159-181. London: BFI, 1991.

Peters, John Durham. The Marvelous Clouds. Toward a Philosophy of Elemental M edia. Chicago: The University of Chicago Press, 2015.

Salokangas, Raimo. "M edia History Becomes Communication History - Or Cultural History?" Nordicom_Review (edited by Ulla Carsslon) 23 (1-2), 2002: 101-105.

Scannel, Paddy \& David Gardiff. A Social History of British Broadcasting. Volume One 1922-1939. Saving the Nation. Oxford: Basil Blackwell, 1991.

Thompson, John. P. Ideology and M odern Culture. Critical Social Theory in the Era of Mass Communication. Oxford: Polity Press, 1990.

Thompson, John P. The Media and M odernity: A Social Theory of the M edia. Cambridge: Polity Press, 1995.

van den Braembussche A.A. "Historical Explanation and the Comparative M ethod: Towards a Theory of the History of Society." History and Theory 28, no. 1 (1898): 1-24.

\section{Word account: 7181}

\footnotetext{
${ }^{1}$ M ediatization could be cynically seen as a way to highlight the strategic importance of media research in current and future education politics (Ampuja et. al., "Strong and Weak Forms of M ediatization Theory", 121).

2 Nerone, "M apping the Field of M edia History", 21-22.

${ }^{3}$ See e.g. Ampuja et. al., "Strong and Weak Forms of Mediatization Theory"; Hjarvard, "From Bricks to Bytes", 49.

${ }^{4}$ Hepp, Cultures of M ediatization, 46-54; Krotz, "M ediatization", 30.

${ }^{5}$ Thompson, Ideology and Modern Culture 123; Thompson, The M edia and M odernity.

${ }^{6}$ E.g. Lundby, "Introduction", 3.

${ }^{7}$ Eisenstein, The Printing Revolution in Early Modern Europe, 187-254.

${ }^{8}$ See Deacon and Stanyer, "M ediatization"; Hepp et. al., "M ediatization"; Deacon and Stanyer "'M ediatization and' or 'M ediatization of'"; Lunt and Livingstone, "Is 'mediatization' the new paradigm for our field?"

${ }^{9}$ Deacon and Stenyer, "M ediatization," 1036-1039.

${ }^{10}$ Hepp, "Differentation", 141.

${ }^{11}$ See Author removed, 2011a

${ }^{12}$ Deacon and Stenyer, "M ediatization," 1036-1039.

${ }^{13}$ See Hepp et. al., "M ediatization," 318-319; Krotzt, "M ediatization," 257.

${ }^{14}$ E.g. Krotz, "M ediatization."

${ }^{15}$ Hepp, "Differentation".

${ }^{16}$ M eyrowitz, No Sense of Place, 83.

${ }^{17}$ Deacon and Stanyer, "M ediatization," 1038.

${ }^{18} \mathrm{lbid}$

${ }^{19}$ Hjarvard, "The M ediatization of Society," 10

20 See e.g. Lange, Comparative-Historical M ethods.

${ }^{21}$ Deacon and Stenyer, "M ediatization."
} 
${ }^{22}$ Hepp et. al., "Mediatization," 318-321.

${ }^{23}$ See Author removed \& Author removed 2008; Author removed 2011b.

${ }^{24}$ Hepp et. al., "M ediatization."

${ }^{25}$ Braembussche "Historical Explanation and the Comparative Method." 22.

${ }^{26}$ Hepp, "M ediatization," 7.

${ }^{27}$ Lunt and Livingstone, "Is 'mediatization' the new paradigm for our field?" , 464-465.

${ }^{28}$ Nerone, "Approaches to M edia History", 98.

${ }^{29}$ Peters, The Marvelous Clouds.

${ }^{30}$ Krotz, "M ediatization," 24.

${ }^{31}$ Ginzburg, The Cheese and the Worms.

${ }^{32}$ See e.g. Burke, History and Social Theory, 95-101.

${ }^{33}$ Ginzburg, The Cheese and the Worms, xxiv.

${ }^{34}$ See Briggs and Burke, A Social History of the M edia, 61-66.

${ }^{35}$ Aries, "Introduction."

${ }^{36}$ Aries, "Introduction," 2.

${ }^{37}$ Balbi, "Radio before Radio," 791, n19.

${ }^{38}$ Author removed, 2013: 16, n7.

${ }^{39}$ Coffee breaks became common at Finnish workplaces in the early twentieth century and they had been an issue of industrial action as early as 1913 when workers demanded coffee breaks in the afternoon as well - in addition to morning coffee breaks (Kettunen, "Työväenkysymyksestä henkilöstöpolitiikkaan, 275.

${ }^{40}$ E.g. O'Sullivan, "Television Memories and Cultures of Viewing, 1950-65," 171.

${ }^{41}$ Hartley, Uses of Television.

42 Thompson, Media and Modernity, 183, 192, 195.

${ }^{43}$ Author removed, 2011a, 301-302.

${ }^{44}$ Of the latest research on Gutenberg's printing press technology and business history, see Dittmar, "New M edia, Competition and Growth."

${ }^{45}$ Nerone, "Approaches to M edia History".

${ }^{46}$ Bösch 2011, M ediengeshichte, 9-10. In Finland, media studies were patterned mostly on the German newspaper studies tradition (Zeitungswissenschft); that is, until the influence of the Anglo-American M CR tradition in the 1960s and cultural studies since the 1980s. The change of tradition also meant that history was almost absent from Finnish media studies until the 1990s. All the major media history projects, such as the ten-volume history of Finnish newspapers and magazines, were produced by historians.

${ }^{47}$ See e.g. Scannel \& Cardiff, A Social History of British Broadcasting.

${ }^{48}$ Salokangas, "M edia History Becomes Communication History - Or Cultural History?", 103-104.

${ }^{49}$ Author removed 2003.

50 Nerone, "Approaches to M edia History", 98.

${ }^{51}$ Burke, History and Social Theory, 97-98. 